\title{
Long term subfossil Cladocera record from the partly varved sediment of Lake Tiefer See (NE Germany)
}

\author{
Krystyna Szeroczyńska* \\ Institute of Geological Sciences, Polish Academy of Sciences, Research Centre Warsaw, Twarda 51/55, PL 00818 Warsaw, Poland \\ *Corresponding author: kszerocz@twarda.pan.pl
}

\begin{abstract}
The partly varved and well-dated sediment record of Lake Tiefer See (NE Germany) allowed the high resolution paleolimnological reconstruction of the lake evolution during the whole Holocene. This paper presents results of subfossil Cladocera analysis. During the Holocene, the fauna of subfossil cladoceran was represented by 36 species belonging to 6 families. Cladocera were dominated by typical open-water species, belonging especially of the Bosminidae family. The sediment record of Lake Tiefer See exhibited distinct decadalto centennial-scale alternations of well- and non-varved intervals, which were related to changes in the thermal circulation of the lake water column. In general, well varved sediments were deposited during periods of reduced lake circulation, and were characterised by maximum abundance of Cladocera, whereas non-varved sedimentation phases occurred during periods of increased lake circulation and showed a lower number of Cladocera specimens. The most suitable conditions for the development of cladoceran fauna occurred during the early Holocene and from $\sim 2055-725 \mathrm{yr}$ cal BP. On the basis of the increasing number of species associated with high lake productivity, eight stages of increasing trophy were inferred. The first two were attributed to climate warming, while the next six to human impact. Higher human driven trophic conditions of Lake Tiefer See occurred in the periods 5750-5500 and 4500-4100 yr cal $\mathrm{BP}$, and four times from 1000 to $50 \mathrm{yr}$ cal BP. During the last 750 years and in the period from 6000 to $2500 \mathrm{yr}$ cal BP, the species of Eubosmina produced extreme morphs. The cyclomorphosis of Eubosmina was likely connected to more pronounced changes in the lake environmental conditions
\end{abstract}

Key words: Lake Tiefer See; Holocene; subfossil Cladocera; Eubosmina morphs.

Received: September 2016. Accepted: November 2016.

\section{INTRODUCTION}

Annually laminated (varved) lacustrine deposits enable high resolution reconstruction of past environmental and climate changes. Since such sediments are relatively rarely deposited in lakes, and are therefore seldom analysed, they represent important material for paleolimnological studies. A number of studies primarily deal with issues related to laminae, such as the process of their formation and preservation (Brauer and Casanova, 2001; Zolitschka et al., 2015; Kemp, 2016) and methods for searching for lacustrine sediments, especially those with well-preserved annual lamination (Brauer et al., 1999; Brauer, 2004; Mingram et al., 2007; Tylman et al., 2012; Wulf et al., 2016). An important issue regards also type and structure of laminae (Sturm, 1979; Sturm and Lotter, 1995; Zolitschka, 2007).

Lake Gościąż (Poland), which was investigated in the 1990s and presents annually laminated lacustrine sediments deposited during the last ca. 13000 years, has become a reference site for Central Europe and a stimulus for a number of further extensive search for lakes with visible, well-preserved annually laminated sediments (Brauer and Casanova, 2001; Kinder et al., 2013; Tylman et al., 2013). Especially lakes with a complete sequence of lamination from their initial period to present day represent the most valuable study material. These deposits allow the annual resolution of the lake chemical and biological (e.g., deposited plant and animal remains) composition, which are recorded by the varves. An important aspect of varved sediments is their seasonal lamination (summer-winter), which implies that both ecological and climatic changes occurring in the past can be followed with an extremely high accuracy (Ralska-Jasiewiczowa, et al., 1998; Szeroczyńska, 1998a; Last and Smol, 2001; Nykänen et al., 2010). The remains of invertebrates, Cladocera in particular, are an important, well preserved and taxanomically well known autochthonous element of lacustrine sediments, and due to their role of primary consumers they are considered to be important bioindicators of both bottom up and top-down ecological drivers of lakes (Hann et al., 1994; Manca and Comoli, 1996; Szeroczyńska, 1998b; Jeppesen et al., 2000; Korhola and Rautio, 2001; Chen et al., 2010; Niska and MirosławGrabowska, 2015). Sediment remains of Cladocera are one of the basic elements of the paleolimnological analysis (Boucherle and Züllig, 1983; Hall and Smol, 1996; Van Damme and Kotov, 2016). 
The analysis of subfossil Cladocera was performed for a number of lake locations in Europe, but mostly nonvarved deposits were analysed (Sarmaja-Korjonen, 2001; Kamenik et al., 2007; Manca et al., 2007; Zawisza and Szeroczyńska, 2007; Bennion et al., 2011; Kulesza et al., 2011; Mirosław-Grabowska and Zawisza, 2014; Zawiska et al., 2015; Nevalainen and Luoto, 2016; Milan, 2016). On the contrary, studies on the subfossil Cladocera fauna in varved sediments was conducted for only some locations in Europe so far, mainly in Germany, Poland, Switzerland and Scandinavia (Hofmann, 1993a, 2001; Szeroczyńska, 1998a; Nykänen et al., 2010).

The annually laminated sediment record from Lake Tiefer See allowed the detailed reconstruction of climate and environmental changes during the Holocene (Kienel et al., 2013; Dräger et al., 2016; Wulf et al., 2016). The present study presents the results of subfossil Cladocera analysis performed on the entire sediment record from Lake Tiefer See (NE Germany). The main objectives of this study were to reconstruct the long term evolution of the Cladocera community and to describe the ecological conditions of the lake from its origin to the modern time. Furthermore, this study aimed also at comparing the results obtained from the analysis of Cladocera remains collected from Lake Tiefer See, with those previously obtained from Lake Gościąż (Central Poland). Lake Gościąż was selected for its comparable geographical location and environmental features respect to Lake Tiefer See and for the fact that so far this represents the sole lakes with almost entirely varved sediments, where analysis of subfossil cladoceran was performed.

\section{METHODS}

\section{Principal study sites: Lake Tiefer See}

Lake Tiefer See is located in NE Germany $\left(53^{\circ} 35.5^{\prime} \mathrm{N}\right.$, $\left.12^{\circ} 31.8^{\prime} \mathrm{E}\right)$ in the region of Mecklenburg Vorpommern (Fig. 1). The lake originated during the last glaciations and well-varved, poorly- varved and non-varved sediments
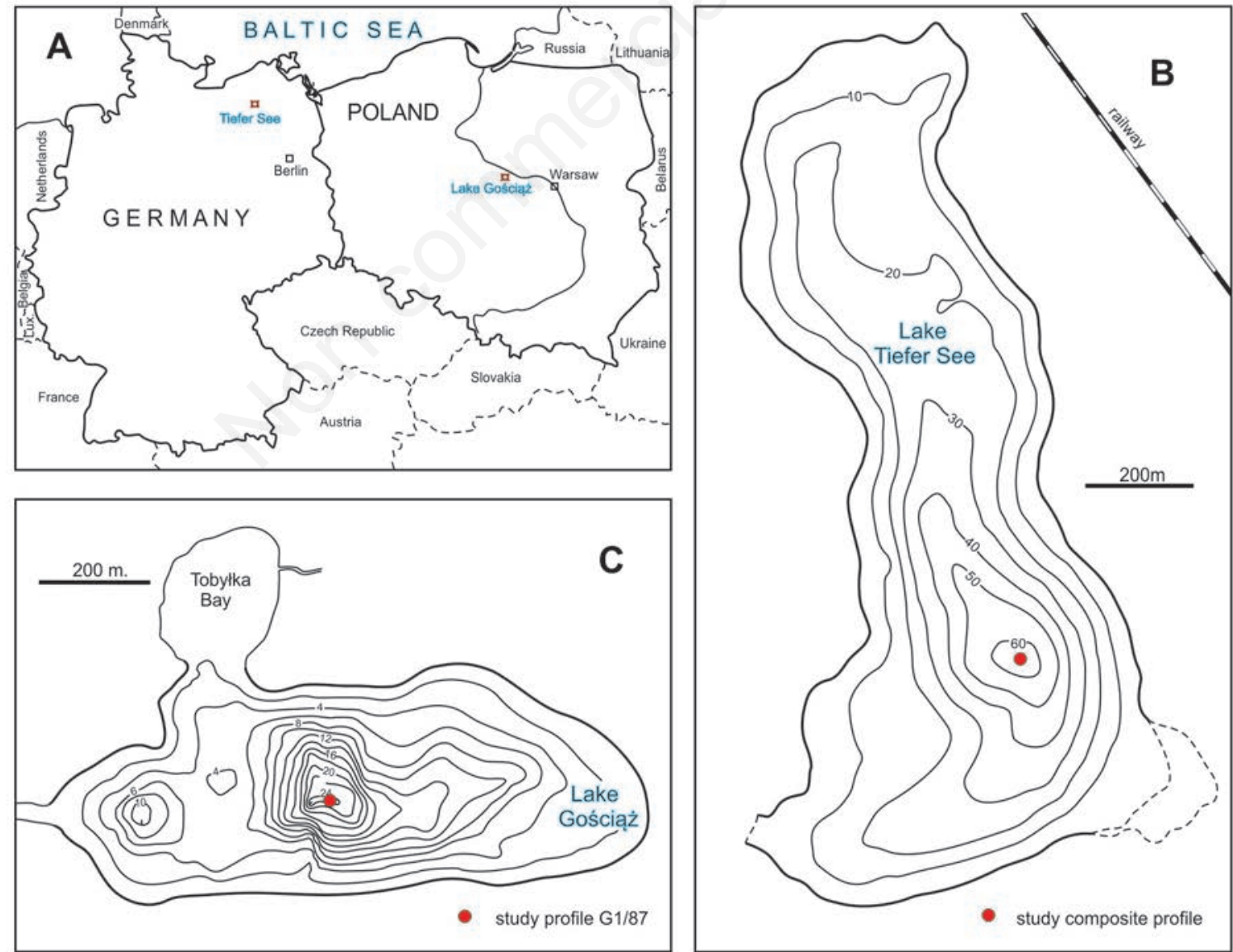

Fig. 1. A) Location of Lake Tiefer See (Germany) and Lake Gościąż (Poland). B) Bathymetric map of Lake Tiefer See. C) Bathymetric map of Lake Gościąż. 
were deposited in the lake since its initial stages. Lake Tiefer See is located at an altitude of $62 \mathrm{~m}$ asl, has an area of about $0.75 \mathrm{~km}^{2}$, and a maximum depth of $62 \mathrm{~m}$. The lake is $1 \mathrm{~km}$ long and its maximum width is around $400 \mathrm{~m}$. The lake is located in the German region affected by oceanic climate, where average January air temperature is $0^{\circ} \mathrm{C}$ and July temperature about $18^{\circ} \mathrm{C}$. Currently the lake is a dimictic to monomictic, mesotrophic, with electric conductivity of $575 \mu \mathrm{S} \mathrm{cm}^{-1}$ (Kienel et al., 2013; Dräger et al., 2016).

In 2011 and 2013 several sediment cores were collected, on which basis a composite $1083 \mathrm{~cm}$ long profile was constructed (Dräger et al., 2016). Due to sediment loss during coring, the sediment profile contains two gaps (at $769.5 \mathrm{~cm}$ $956.5 \mathrm{~cm}$ depth), each one probably of several decimetres length (Fig. 2). Due to these gaps a continuous composite profile could only be constructed for the upper $770 \mathrm{~cm}$ of the sediment profile, covering the past ca. 6000 years. The chronology for the upper part of the profile was established by a multiple dating approach, including varve counts, AMS ${ }^{14} \mathrm{C}$ dating, and tephrochronology (Kienel et al., 2013; Dräger et al., 2016; Wulf et al., 2016). Chronology uncertainties vary along the sediment record and amount to \pm 85 years at the base of the studied interval at $6030 \mathrm{yr}$ cal. BP. The poor age control in the lower part of the sediment profile, i.e. below $770 \mathrm{~cm}$ depth only, allowed a descriptive data evaluation. The lacustrine sediment deposition started at about $1070 \mathrm{~cm}$ depth, and early sediments were mainly composed of calcite, plant remains and minerogenic detritus. From ca. $1040 \mathrm{~cm}$ depth upwards, organic rich sediments were characterized by alternating well-varved, poorly varved and non-varved sediment sequences. Well-varved sediments are mainly composed of sublayers formed by carbonates (calcite and Ca-rhodochrosite), diatoms and organic matter (Dräger et al., 2016; Wulf et al., 2016). Poorly- and non-varved sediment sections are enriched in quartz grains, plant fragments, benthic diatoms and occasionally bivalves. All ages in this study are given as calibrated years before present (yr cal BP), and as Anno Domini (AD) years in the historic period.

\section{Site for comparison study: Lake Gościąż}

Lake Gościąż $\left(52^{\circ} 35^{\prime} \mathrm{N}, 19^{\circ} 21^{\prime} \mathrm{E}\right)$ is located on the Vistula terrace (central Poland, Fig. 1) and belongs to a complex of four connected lakes (Na Jazach lake system, Gostynińskie Lake District). The lake is located at 64.3 $\mathrm{m}$ asl, its current area is $41.7 \mathrm{ha}$, its maximum depth is $24 \mathrm{~m}$, and its mean width and length are $\sim 400 \mathrm{~m}$ and 1168 $\mathrm{km}$, respectively. The lake is located in the oceanic climate zone with average January air temperature of $-2.8^{\circ} \mathrm{C}$

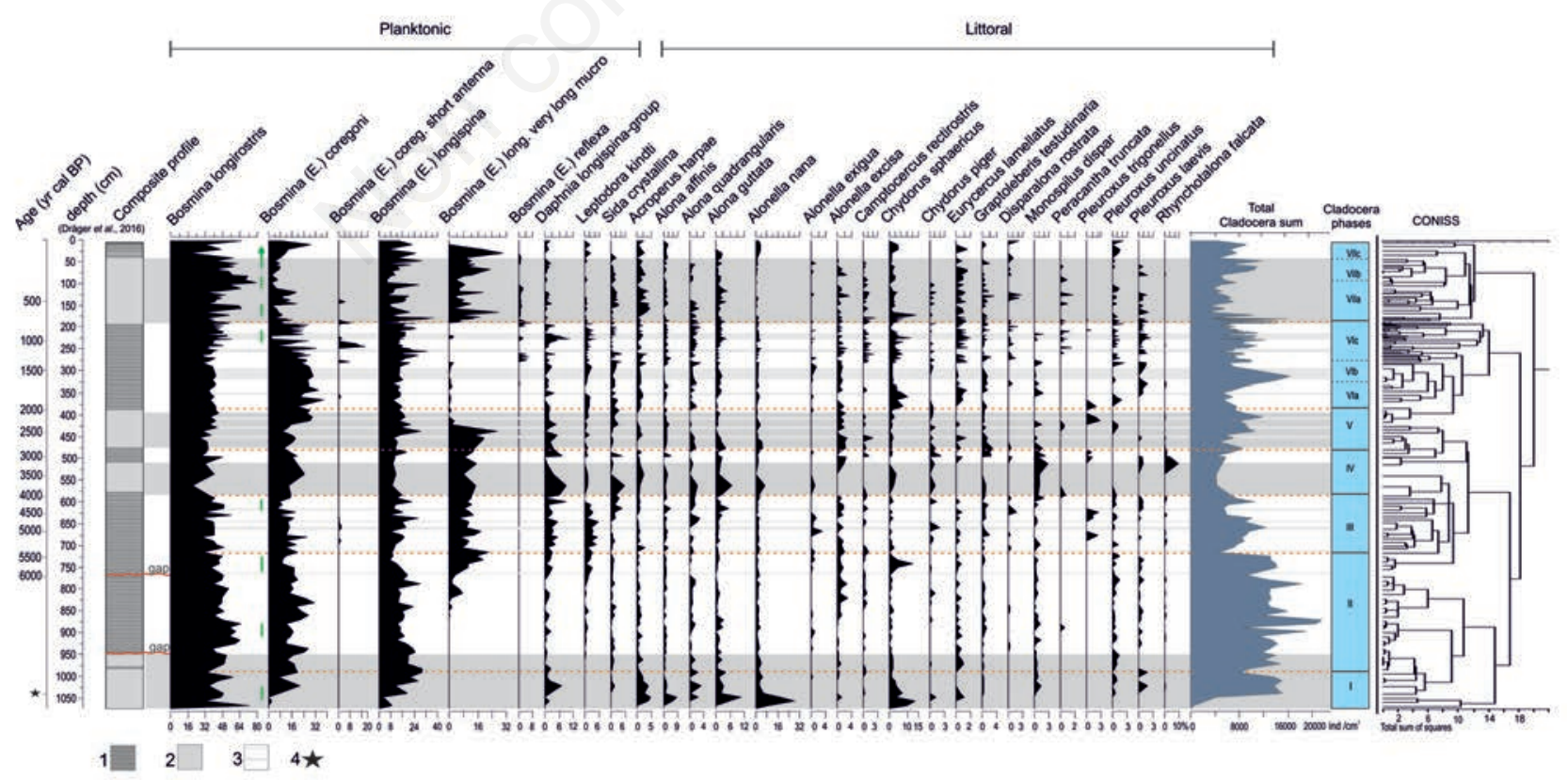

Fig. 2. Percentage composition of the subfossil Cladocera species, and total Cladocera sum in the sediments of Lake Tiefer See (composite profile). Dotted vertical grey arrows (on Bosmina longirostris) indicated stages of trophic increase. 1, section with well developed varved (regular laminae); 2, non-varved section; 3, poorly varved section; 4, 11,492 \pm 253 yr cal BP $\pm 2 \sigma$ (Dräger et al., 2016). 
and July temperature of ca. $18^{\circ} \mathrm{C}$ (Ralska-Jasiewiczowa et al., 1998), and is currently in mesotrophic to eutrophic conditions. Lake Gościąż was formed during the last glaciations. During the Late Glacial and the Holocene, sediments of gyttia type were deposited in the lake. They are well varved, except for the youngest sediments (especially since about $1550 \mathrm{yr}$ cal BP, profile G1/87).

\section{Cladocera analysis}

The analysis of subfossil Cladocera was performed at $2-5 \mathrm{~cm}$ resolution for the last 6000 years of sedimentation at Lake Tiefer See, i.e. from 0 to $770 \mathrm{~cm}$ sediment depth, while the sediments below $770 \mathrm{~cm}$ depth were analysed at $5-10 \mathrm{~cm}$ resolution $(700-1065 \mathrm{~cm})$. Due to the two gaps located at ca. 770 and $957 \mathrm{~cm}$ depth (Fig. 2), a robust chronology exists only for the upper $770 \mathrm{~cm}$ of the sediment profile (Dräger et al., 2016). Therefore, the Cladocera data obtained from the topmost $770 \mathrm{~cm}$ are presented both with respect to the time and depth scale, whereas data below $770 \mathrm{~cm}$ are presented only along the depth scale, and hence are only presented in a descriptive way.

Sediments were analysed for physical parameters and mineralogical composition (Dräger et al., 2016). The analysis of subfossil Cladocera was performed in accordance with the generally accepted standard methods (Frey, 1986; Korhola and Rautio, 2001). After removal of carbonates, each sample $\left(1 \mathrm{~cm}^{3}\right.$ of fresh sediment) was macerated in a $10 \%$ $\mathrm{KOH}$ solution, and washed through a $33 \mu \mathrm{m}$ sieve. The obtained residuum was analysed under an optical microscope (OLYMPUS) at 100 to 400 magnifications. Cladocera species were identified based on the studies by Hofmann (1993b, 1999), Flössner (2000), Szeroczyńska and SarmajaKorjonen (2007) and Korosi et al. (2010). Cladocera ecological preferences were defined as in Flössner (2000), and Błędzki and Rybak (2016). The percentage composition of Cladocera, the ratio of planktonic to littoral species, and the total number of identified individuals in $\mathrm{cm}^{3}$ sediment were graphically represented using C2 (Juggins, 2007), while the homogeneous Cladocera zones were identified using the CONISS statistical method. Tentative statistical analyses of Cladocera results provided no significant correlation between Cladocera and geochemical proxies (see Dräger et al., 2016 for further details). The exception is represented by the last ca. 100 years, which are characterized by higher trophic conditions, increasing organic carbon and calcite contents, which resulted to be related to changes in subfossil Cladocera (Kienel et al., 2013).

The results of the morphological analysis of Cladocera remains from Lake Tiefer See were compared with the results obtained in the 1990s for the laminated sediments of Lake Gościąż (with a resolution ranging from 10 to 50 years), which were published in a monographic study (Ralska-Jasiewiczowa et al., 1998; Szeroczyńska, 1998a).

\section{RESULTS}

The subfossil Cladocera fauna in the sediments from Lake Tiefer See was represented by 36 species belonging to 6 families (Fig. 2). Pelagic Cladocera species dominated during the whole history of the lake, especially those belonging to the family Bosminidae Baird. Littoral individuals from the family Chydoridae Stebbing, were represented by numerous species but showed with very low frequency (Figs. 2 and 3). Fig. 3 shows the comparison of long term changes in the proportion of pelagic and littoral cladoceran species in the partially varved Lake Tiefer See and in the completely laminated Lake Gościąż.

As mentioned before, no significant relation was found between changes of the Cladocera assemblage and geochemical sediment parameters. The exception is represented by the last ca. 100 years, which are characterized by higher trophic conditions, increasing organic carbon and calcite contents, which resulted to be related to changes in subfossil Cladocera (Kienel et al., 2013). While the sediment records included four distinguished units with well-varved sediments and four units with poorly or non-varved sediments (Fig. 2), the CONISS analysis revealed seven main cladoceran zones in relation to the species composition and the total number of cladoceran specimens, which correspond to the development phases of the lake. The first two phases corresponded to the sediment interval below $770 \mathrm{~cm}$ depth, while the last 6000 years are subdivided in five phases (Fig. 2).

In phase I $(1065-970 \mathrm{~cm})$ the Cladocera were represented mainly by pioneer species, i.e. Alonella nana Baird (up to 29\%), Chydorus sphaericus (O.F. Müller) (up to $13.5 \%$ ), Alona affinis (Leydig) (up to 8.3\%) and Acroperus harpae (Baird) (up to 4.7\%, Fig. 2). Planktonic species were dominated by forms occurring also in shallow waters, such as species from the group of Daphnia longispina O.F. Müller and Bosmina longirostris (O.F. Müller). The density of Cladocera individuals gradually increased and at the end of the phase reached the number of 15,150 individuals per $1 \mathrm{~cm}^{3}$ (ind $\mathrm{cm}^{-3}$ ) of sediment (Fig. 2). During the phase II $(970-715 \mathrm{~cm})$ Cladocera reached the highest density in the sediment profile, i.e. 21750 ind $\mathrm{cm}^{-3}$ at the depth of $871 \mathrm{~cm}$ (Fig. 2). The beginning of this phase was characterized by the dominance of planktonic forms, including mainly species of the family Bosminidae (Figs. 2, 3 and 4). In particular the specie B. longirostris, which is a species preferring waters rich in nutrients, reached $64.5 \%$ of the total Cladocera abundance while the relative abundance of the species $E u$ bosmina Seligo group was over $30 \%$. Particularly noteworthy are the extreme morphs produced by species of the group Bosmina (E.) longispina Leydig (Brooks and Dodson, 1965), which were observed at the end of phase II (Fig. 5). These forms were characterised by unusual 
length of mucrones on carapaces (Fig. 5). Phase II was also distinguished by the increased abundance of $C$. sphaericus (14\%), a littoral species occurring mostly in the pelagic zone, as well as of Alonella excisa (Fischer) (up to $4 \%$ ), an acidophilous littoral species.

As well as in phase II, also in phase III $(715-584 \mathrm{~cm}$, ca. 5400-4076 yr cal BP) planktonic forms were mainly represented by Bosminidae with a very long mucro. Moreover, this phase was characterized by the appearance of Bosmina (E.) coregoni Baird with very short antennae, and by high densities (up to 5.6\%) of the planktonic predatory species Leptodora kindti (Focke).

During the phase IV (584-477 cm, ca. 4076-2890 yr cal BP) the cladoceran zooplankton registered a decrease in "eutrophic" species B. longirostris and an increase in Eubosmina group. Extreme morphs occurred in slightly smaller numbers compared to the previous phase, which was also accompanied by the reduced count of $L$. kindti. Noteworthy is the increased development of species of the group D. longispina (over 10\%). Among littoral species, Monospilus dispar Sars and Rynchotalona falcata (Sars) reached the maximum abundance, i.e. over $3 \%$ and
$9.6 \%$, respectively. Cladocera reached here the lowest density in the history of Lake Tiefer See, which ranged from 4250 to 6550 ind $\mathrm{cm}^{-3}$.

Phase V (477-389 cm, ca. 2890-2055 yr cal BP) was distinguished by a significant abundance (up to $30 \%$ ) of $B$. (E.) longispina with very long mucros (Fig. 2). Species of the $D$. longispina group also occurred in relatively large numbers, as well as the acidophilous littoral species $A$. excisa and Graptoleberis testudinaria (Fischer).

Phase VI (389-185 cm, ca. 2055-725 yr cal BP) was characterised by large fluctuations in the frequency of both planktonic and littoral species (Fig. 3), based on which three sub-phases were distinguished (VIa, VIb, VIc; Fig. 2). Frequency of Cladocera specimens increased from 5150 ind $\mathrm{cm}^{-3}$ in VIa to 16,350 ind $\mathrm{cm}^{-3}$ in VIb and only a very few extreme morphs were found in these subphases. Subphase VIc was characterised by the presence of Eubosmina species with very short antennae, and by Bosmina (E.) reflexa Seligo, which was identified for the first time in this layers. Pleuroxus leavis Sars and $C$. sphaericus reached in VIa and VIc a considerable abundance over $6 \%$ in the littoral zone, while the total number

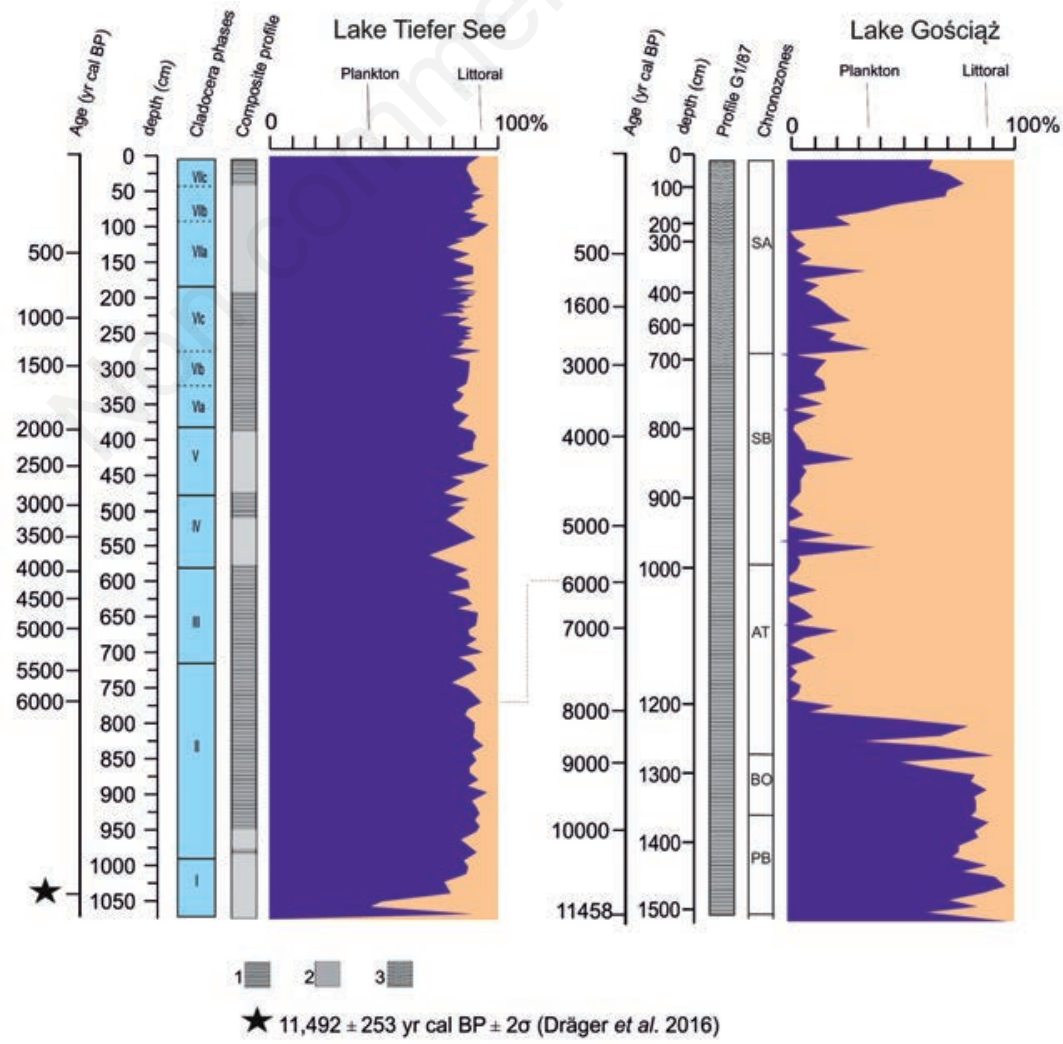

Fig. 3. Comparison of the percentage content of planktonic and littoral Cladocera species from the sediments of Lake Tiefer See (Germany) and Lake Gościąż (Poland). 1, well-varved section (regular laminae); 2, non-varved section; 3, section irregularly laminated. 
of all individuals amounted to more than 16,000 ind $\mathrm{cm}^{-}$

${ }^{3}$ in sub-phase VIb (Fig. 2).

Phase VII (185-0 cm, ca. $725 \mathrm{yr}$ cal BP to modern time) was characterised by large fluctuations in the species frequency, on the basis of which three sub-phases were distinguished (Fig. 2). Phase VII registered a re-occurrence of extreme morphs of $B$. (E.) longispina type with a very long mucro, while the "eutrophic" species $B$. longirostris increased significantly, reaching over $80 \%$ of the relative abundance in sub-phase VIIb. Sub-phase VIIa highlighted an overall decline in the total abundance of Cladocera (Fig. 2), which was accompanied by the complete disappearance of certain species (e.g. Alonella Sars, Pleuroxus Baird, Alona Baird) and a significant contribution of C. sphaericus (up to $0.9 \%$ ). It was observed that planktonic species, especially taxa preferring nutrient-rich waters, developed again at the end of the phase (VIIc), with B. longirostris (ca. 65\%) as a dominant species.

Reconstructed vegetation showed higher openness during the periods ca. 3900-3100, 2700-2200 and $750 \mathrm{yr}$ cal BP (Fig. 4; see Dräger et al., 2016 for further details).

\section{DISCUSSION}

\section{Phases of the lake development}

The analysis of species composition and changes in the frequency of subfossil Cladocera represented in the lacustrine sediments of Lake Tiefer See allowed the reconstruction of the lake evolution. On the basis of the characteristics of Cladocera assemblages in Lake Tiefer See seven main phases of lake development during the Holocene were distinguished.

Phase I corresponded to the initial period of the lake evolution, which is likely attributable to the end of the Late Glacial period and the early Holocene (RalskaJasiewiczowa, 1998; Brauer et al., 1999). Autochthonous lacustrine non-varved sediments were deposited during this stage. The presence of Cladocera pioneer species occurring in association with aquatic vegetation (A. harpae, A. affinis) indicates lower water level or/and pronounced re-deposition of sediment from the littoral zone of the lake. The occurrence of planktonic species (Eubosmina,

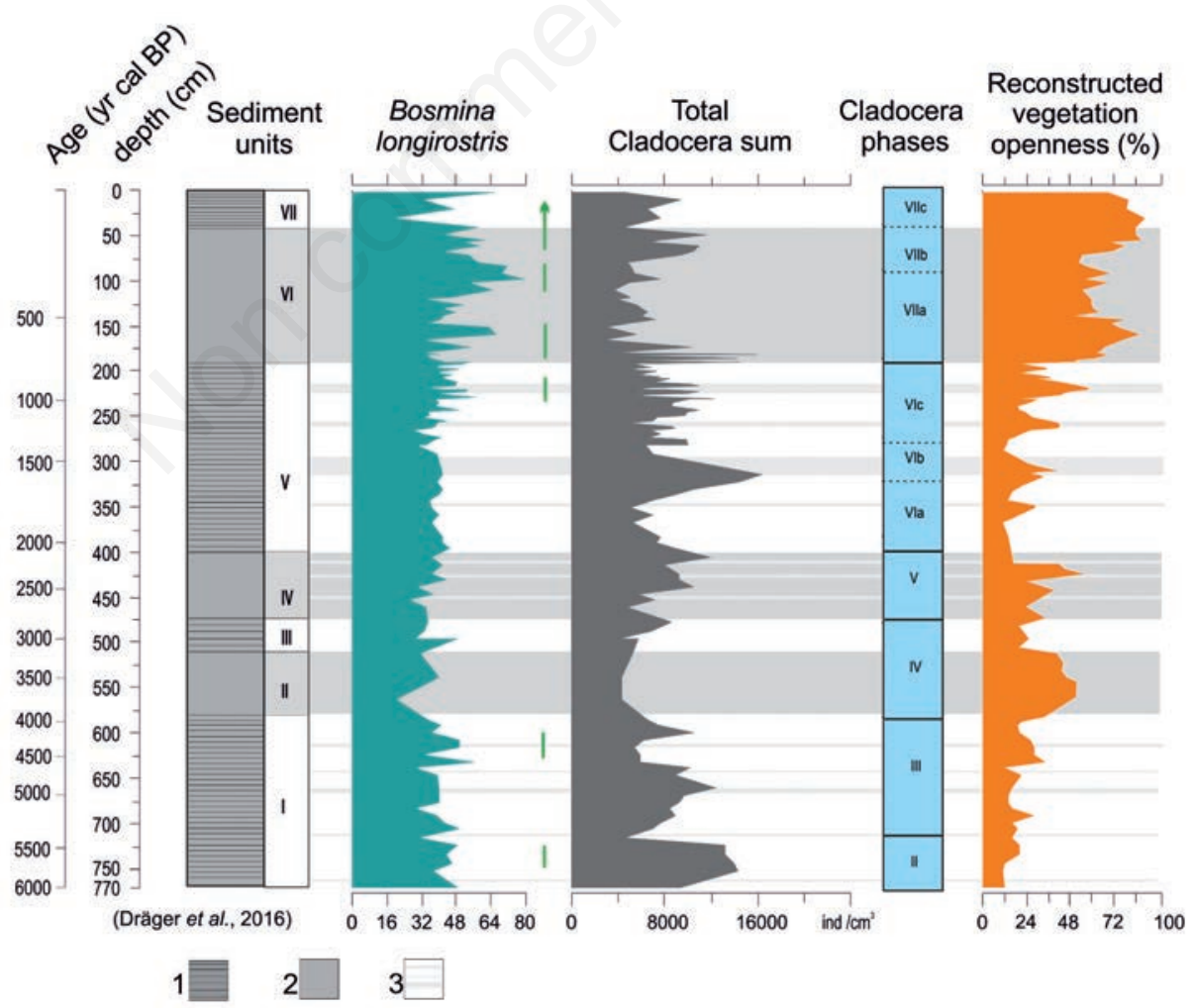

Fig. 4. Comparison between stages of trophic increase (dotted vertical grey arrows) and reconstructed vegetation openness (as an index of settlements phases). Sediment column with varved (units: I, III, V, VII) and non-varved (units: II, IV, VI) sections after Dräger et al. (2016). 1, well-varved section (regular laminae); 2, non-varved section; 3, section irregularly laminated. 
and $D$. longispina group) and the high total number of Cladocera at the end of this phase indicated more stable conditions, and that water temperature and edaphic conditions progressively became very favourable for the zooplankton growth (Frey, 1986; Jeppesen et al., 2000; Korosi and Smol, 2012). Such a picture is often found in lacustrine sediments deposited during the transition between the Late Glacial and the Early Holocene period (Szeroczyńska, 1998a, 2006; Zawisza and Szeroczyńska, 2007; Kulesza et al., 2011; Zawiska et al., 2015).

The species composition of subfossil Cladocera during phase II indicated optimal lake environmental conditions.
During this time well-varved sediments were deposited (with two gaps of sediments in the composite profile). The increased abundance of planktonic [in particular B.(E.) longispina and B.(E.) coregoni], littoral acidophilous species (i.e. Chydorus piger Sars, A. excisa), together with the decrease of species living in association with aquatic vegetation (e.g., A. harpae, A. affinis) indicate alpha/or beta-mesotrophic status and higher water level (Alhonen, 1970; Sarmaja-Korjonen, 2001; Korosi and Smol, 2012). Probably the sediments of phase II were mainly deposited during the Holocene Climatic Optimum. The growth of Cladocera fauna was obviously affected by warm and
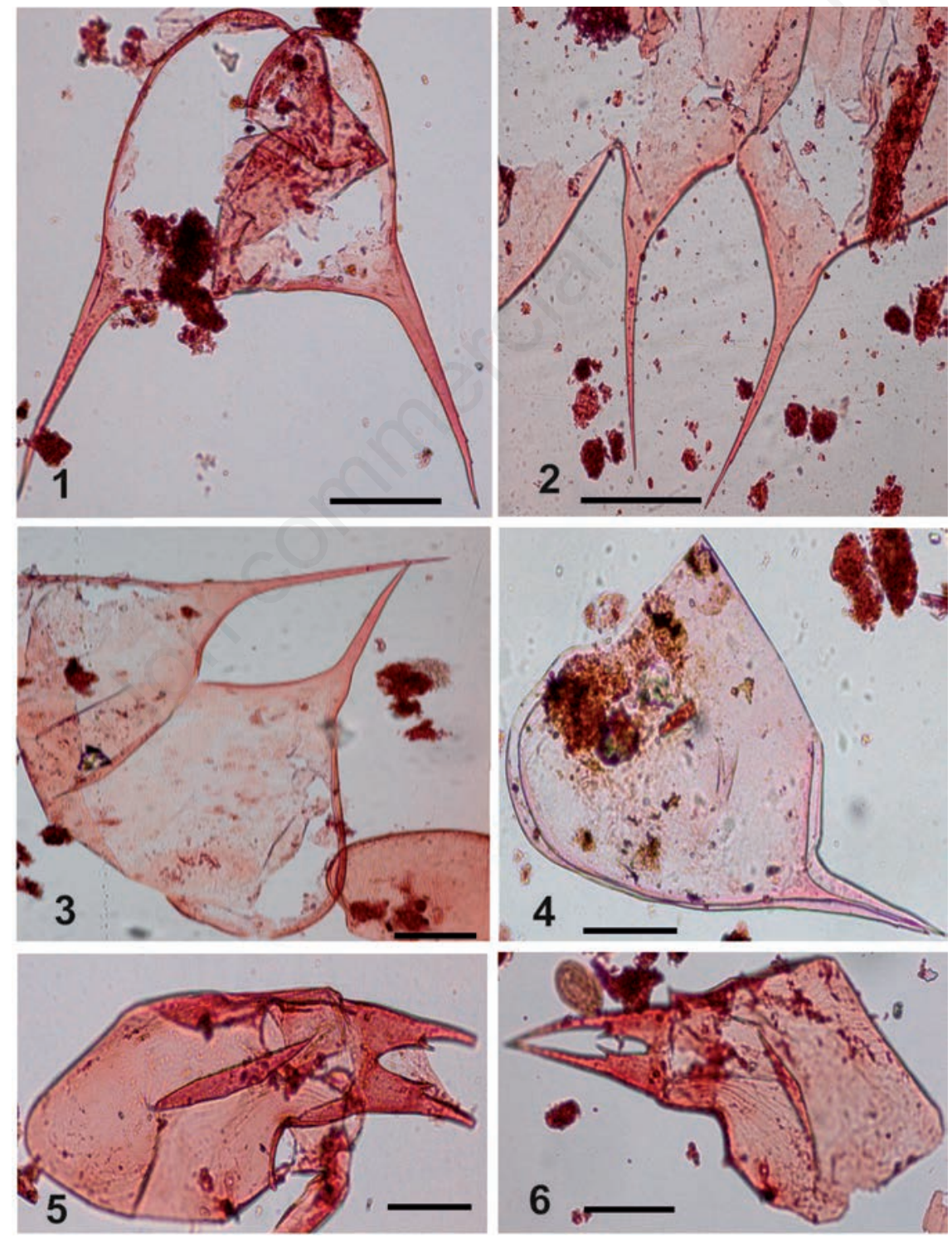

Fig. 5. Remains of Eubosmina extreme morphs. 1-4: shells with very long mucros; 5-6: head shield with very short antennas - head pores Eubosmina coregoni type. Scale bars: $100 \mu \mathrm{m}$. 
humid climate prevailing in the Atlantic period. Noteworthy is the high abundance of $B$. longirostris, a species preferring waters with a higher trophic status, as it confirms the high lake productivity (Szeroczyńska, 1998b; Jeppesen et al., 2000; Manca et al., 2007; De Sellas et al., 2008).

Phase III probably coincided with the first half of the Subboreal period. The deposition of the well-varved sediments continued in the lake during this stage. After the Holocene climate optimum (ca. 8000 to 3500 cal yr BP), during which warm temperature and edaphic conditions prevailed, both planktonic and littoral Cladocera decreased. The observed morphological modifications, i.e. changes in the shape and size of Bosminidae individuals, indicated that either water level oscillations and/or high predation pressure from both invertebrates and fish, as previously outlined by several studies conducted at the lake (e.g. Kerfoot, 1981; Korosi et al., 2008, 2010, 2013; Swetmann and Finney, 2003; Sakamoto et al., 2007; Sakamoto and Hanozato, 2008; Błędzki and Szeroczyńska, 2015).

The climate conditions probably changed during phase IV and became cool (windy) and humid. Such a picture has been often observed during the Subboreal to Subatlantic climate transition (Milecka and Szeroczyńska 2005; Zawisza and Szeroczyńska 2007). Probably water mixing and water-level fluctuations increased at that time (Dräger et al., 2016), thus enhancing water turbulence and turbidity and preventing both a stable deposition of sediments and the development of zooplankton. In fact non-varved sediments were deposited during this time. Higher water turbidity (low transparency) and circulation are generally considered as not conducive to biological production including the growth of Cladocera fauna (Cottenie and De Meester, 2003; Korosi et al., 2013). Such environmental conditions are manifested by changes in the frequency of Daphnia individuals as well as of littoral species. During this phase, lake waters were also probably relatively poor in nutrients, which most likely contributed to the significant drop in the abundance of all Cladocera species. $R$. falcata, which is a littoral species frequently present in Lobelia-type lakes, occurred in large numbers at that time, thus indicating oligotrophic conditions (Milecka and Szeroczyńska, 2005; Błędzki and Rybak, 2016).

Phase V coincided with the initial phase of the humid and relatively colder Subatlantic period (after ca. $2600 \mathrm{yr}$ cal BP). During this phase poorly varved sediment was deposited and the total abundance of Cladocera was only slightly higher compared to phase IV. This period was characterised by the high contribution of extreme forms. Morphological modifications of Bosminidae not only protect them against predators, but may also reduce the effectiveness of swimming and consequently increase the resistance of animals against unfavourable hydrodynamics of water (Gliwicz and Pijanowska, 1989; Gliwicz et al., 2000; Korosi et al., 2013). Perhaps stronger wave motion and frequent water mixing induced an increased production of these extreme morphs. In the second part of the phase, since ca. $2400 \mathrm{yr}$ cal BP, environmental conditions in the lake considerably improved. Bosminidae produced only "normal morphs", and the abundance of plankton increased. The climate became warmer and the water temperature became conducive to the development of the fauna (Gliwicz, 1990; Günter and Lieder, 1993; Jeppesen et al., 2000; Korosi et al., 2013).

After a fairly long period of relatively adverse lake conditions, edaphic and temperature conditions improved during the Phases VI. Well varved sediment (unit VI) was deposited during the warmer part of Subatlantic period, and the total abundance of zooplankton increased. Both pelagic and littoral Cladocera species experienced favourable conditions for their development. During this period, Bosminidae produced only rare extreme morphs, which may indicate a reduced pressure of predators and/or more stable hydrological conditions (Jeppesen et al., 2000; Nevalainen and Luoto, 2016). The water temperature was optimal for the development of most Cladocera species (e.g., P. laevis, Camptocercus rectirostris Schoedler), indicating favourable climate conditions (Błędzki and Rybak, 2016). The record of species indicating increased nutrient availabilities (i.e. Alonella exigua (Lilljeborg), Disparalona rostrata (Koch), Pleuroxus uncinatus Baird), probably reflects short-term fluctuations in the trophic conditions of the water, which might reflect the first human impact on the Lake Tiefer See ecosystem. In fact vegetation openness reconstructed from pollen data has been related to human activity within the lake catchment (Dräger et al., 2016) During phases VII, which spans over the last millennium, non-varved (in subphases VIIa-b) and well varved sediments (unit VIIc) were deposited. The species composition and low Cladocera density indicate that during this part of the Subatlantic period the conditions in the lake were very unstable, thus confirming the types of sediment depositions. The production extreme morphs of Bosmina was supposed to be related to water mixing and water level fluctuations (Hellsten and Stenson, 1995; Lord et al., 2006). The reduced frequency and disappearance of certain species was observed in the sediment deposited ca. 640-440 yr cal BP, and ca. 300 years ago. These changes might be interpreted as the result of both climate cooling and reduction in the lake nutrient level during the Little Ice Age (Dräger et al., 2016). The conditions in the lake changed again during the deposition of the youngest sediments (varved sediment unit in phase VII). The occurrence of taxa indicating higher nutrient availability may indicate an inflow of nutrients into the lake and an increased the zooplankton production both in the pelagic and littoral zone.

The characteristics of both the open water and littoral 
cladoceran fauna along the sediment core from Lake Tiefer See indicated the lake basin as deep during its whole history, and with a well-developed pelagic zone, as indicated by the dominating planktonic species. The most suitable conditions for the development of water fauna occurred during phases II and VI, which well correspond to the deposition of well-varved sediments. On the contrary, lower frequency of cladoceran individuals was observed during stages of non- and poorly varved sediment deposition (especially Cladocera phase IV and sub-phase VIIa). A different situation was noted in the non-varved sub-phase VIIb, where the total number of cladoceran increased, due to the high density of $B$. longirostris, i.e. a species preferring high nutrient availability. This indicates a recent increase in the lake trophic status in relation to anthropogenic impact. The lower cladocera specimen number in poorly- and non-varved intervals in contrast to well-varved sediment phases implies that increased lake circulation might have negatively affected cladoceran populations in the lake, as observed by Jeppesen et al., (2000) and Cottenie and De Meester (2003).

The planktonic B. longirostris and the littoral C. sphaericus occurred with high abundance in Lake Tiefer See. Both species are often dominant in eutrophic freshwater bodies (Alhonen, 1970; Hofmann, 1996; Szeroczyńska, 1998a, 1998b; Korhola and Rautio, 2001; Sarmaja-Korjonen, 2001; Schmidt et al., 2001). However, taking into account the high occurrence of other pelagic species, which prefer lakes with lower trophy, it can be presumed that Lake Tiefer See was never extremely eutrophic, and the lake oscillated during its evolution between alpha- and beta-mesotrophic status. Eight stages of increasing trophy, indicated by species associated with high lake productivity, were identified, in particular between 5750-5500, 4500-4100 and $750-50 \mathrm{yr}$ cal BP. Increases in the nutrient availability were likely more related to climatic conditions during the early Holocene, and to combined climate and anthropogenic factors during the late Holocene. Increasing abundance of $B$. longirostris indicated higher productivity and an increased contribution of this species to the cladoceran fauna of Lake Tiefer See was also observed in earlier periods, especially during the first stage of the lake development, which was accompanied by a considerable growth of littoral species. Sediments of many lakes (both deeper and shallow, lowland and mountain lakes) show such a picture in the early Holocene (Szeroczyńska, 1998a, 2006), when climate warming, and hence the rise in water temperature, provided good conditions for the development of flora and fauna. The second major increase in the abundance of $B$. longirostris in Lake Tiefer See was observed at a depth of ca. $900 \mathrm{~cm}$, which was accompanied by the maximum increase in the number of species individuals. Such a picture is often observed during the Holocene Climate Optimum when the plankton, reached the maximum growth especially in deeper lakes (Milecka and Szeroczyńska, 2005). The increased trophic status of the lake observed during the period from approximately $6000 \mathrm{yr}$ cal BP to the modern times was mainly the effect of anthropogenic activity, rather than climate. However, not all periods of anthropogenic activity are reflected by changes in productivity of Lake Tiefer See, such as phase IV and V, non varved sediments units II and IV. A probable cause might be the increased circulation in the lake during these intervals (restricted transmission of light) which significantly influences Cladocera growth.

Comparable trophic changes in response to human impact, i.e. during the periods 5850-5450, 4400-3800, 1950$1700 \mathrm{yr}$ cal BP, have been reconstructed on the basis of subfossil Cladocera analyses in Lake Gościąż (RalskaJasiewiczowa et al., 1998; Szeroczyńska, 1998a). Similarly as in Lake Tiefer See, the highest increase in the trophic status occurred in the period from $750 \mathrm{yr}$ cal BP until the modern times. Generally Lake Gościąż was classified as meromictic, mesotrophic, while Tiefer See is dimictic, and maintained an oligo- or mesotrophic character during its development. At present Lake Gościąż, unlike Lake Tiefer See, is classified as eutrophic. Despite the fact that Lake Gościąż is even more isolated from the direct human impact, the process of eutrophication is much faster compared to Lake Tiefer See. This is primarily due to its much smaller depth and constant stratification (meromixis).

\section{Cladocera morphology}

Interestingly, different morphological types of $B$. longirostris, B.(E) coregoni and B.(E) longispina were observed along the sediment profile. Forms of $B$. (E) coregoni showed pronounced variability of mucro length on shell, antennae length, together with the head shield. All identified forms of the species and its subspecies had head pores on the head shield, which are characteristic of $B$. (E) coregoni types. Other lake sediment studies conducted in Europe have outlined the presence of species of Eubosmina with different morphological characteristics, such as $B$. (E) coregoni with a short or no mucro and long antennae, B. (E) longispina and B.(E) reflexa with a mucro of varying size (Hofmann, 1996; Gasiorowski and Szeroczyńska, 2004; Faustova et al., 2011; Błędzki and Szeroczyńska, 2015). As most of the lakes, where these forms have been identified, are mesotrophic, it may be assumed that trophic conditions and water temperature are the decisive factors for the existence of different $E u$ bosmina subspecies. Hofmann (1993b; 1996) determined high diversity of Eubosmina by measuring the mucro length and determined that the variability of Eubosmina species was evolutionary. In his papers on lakes Grosser Segebergersee, Grosser Plönersee and Bodensee (Lake Constance), Hofmann (1984) described cladoceran species that are characteristic of a given climate period. 
Different morphological characteristics of the species $B$. (E) longispina were present in Late Glacial times, of Bosmina (E) coregoni f. kessleri Uljanin in the Boreal and Atlantic period, and of $B$. (E) coregoni in the youngest Subboreal and Subatlantic period. However, in the non varved Polish lakes Ostrowite and Charzykowskie (Milecka and Szeroczyńska, 2005; Błędzki and Szeroczyńska, 2015) and in Lake Tiefer See (Germany), an alternating (non-evolutionary) occurrence of different Eubosmina forms was found at different sediment depths. Despite the similarities between the two varved lakes Tiefer See and Gościąż, the latter showed a pronounced scarcity in the abundance of Bosminidae and, in particular, the lack of extreme morphs. This raises an important question of why there were so many morphs in Lake Tiefer See and what was the main cause of their increased production. Furthermore, it is still not known whether the development of different morphs is connected with thermal or other physical conditions, or to water chemical changes.

The results from the analysed lakes in Poland and Germany allow the assumption that the change in lake productivity was the driver for morphological variability of Cladocera. In Poland, subfossil Cladocera were analysed mainly in lakes with higher trophic status, from mesotrophic to hypertrophic, while studies on sediments from deep oligotrophic mountain lakes revealed a practically complete absence of species belonging to the Bosminidae family. Oligotrophic lakes in the Tatra Mountains (Szeroczyńska, 2006; Sienkiewicz and Gąsiorowski, 2016), probably had such a low availability of nutrients during the whole Holocene, that edaphic conditions were almost never suitable for the Bosminidae existence. $B$. longirostris was found only in the sediment deposited during the modern time. It seems that the occurrence of Bosmina, especially B.(E) coregoni and its morphological variants, is mainly related to edaphic conditions (Cottenie and De Meester, 2003), and it can be assumed that the mesotrophic state of waters is favourable for the development of some variations of Eubosmina (Hofmann, 1996; Korosi et al., 2010). Probably the mesotrophic status of Lake Tiefer See provided good conditions for abundant occurrence of planktonic species, but the question still remain on what factors can induce the development of these varieties, including extreme morphs? Why Eubosmina morphs characterised by a very small head shield with very short antennae occurred only in varved sediment intervals, while morphs with very long mucros dominated in non-varved sediment sections? Such forms were also found in varved sediments deposited in the period 5500$4000 \mathrm{yr}$ cal BP. For years the occurrence of different morphs of Bosminidae represented a problematic issue for the researchers (Brooks and Dodson, 1965; Kerfoot, 2006; Sakamoto and Hanazato, 2008; Błędzki et al., 2013;
Korosi et al., 2013; Błędzki and Szeroczyńska, 2015). Most researchers suggest that the main reason for producing morphological variations is the adaptation of the species to extreme conditions. The variations in size and the production of different morphs protect the individuals from predation. In the case of Bosminidae, it provides protection from predation by other invertebrates. In fact it has been shown that Bosminidae often reduces their body size to get protected from predation by Copepoda (Sakamoto and Hanazato, 2008). Another adaption consists in a significant increase of the body size (e.g., extending antenna or mucro) to reduce the risk of predation from other Cladocera, such as L. kindti. These morphological changes could be observed in Lake Tiefer See, where the increased frequency of $B$. (E.) longispina with a very long mucro correlates with high relative abundance of $L$. kindti. Through the mechanism of direct identification of predators, also Daphniidae Straus can significantly reduce or increase their body size by producing high helmets and long spines to be protected from fish predation. However, not only their ability to detect the threat from predators, but also environmental factors may cause morphological changes. The increase in water temperature as well as seasonal and chemical changes can also support the formation of different morphs (Gliwicz, 1990; Moore and Folt, 1993; Sakamoto and Hanazato, 2008; Korosi et al., 2013). The modified morphology can reduce the swimming efficiency and increase the resistance of animals to water turbulence. This seems to be the probable explanation of extreme morphs found in varved lake sediments and other morphs found in non-varved sediments in Lake Tiefer See. It can be supposed that in periods of non-varved sedimentation, the lake water was less transparent and more turbulent, what induced Bosminidae to produce morphs provided with more physical stability and slower movement (Gliwicz and Pijanowska, 1989). This caused no disadvantage in the case of homogenous distribution of the food due water turbulence. Thus, morphological variations support the survival of individuals in unstable and less favourable biotic and abiotic conditions, which include pressure by predators (invertebrates and fish), temperature, strong water movements and rapid chemical variability.

\section{CONCLUSIONS}

The species composition of Cladocera determined in varved and non-varved sediments showed that Lake Tiefer See was a deep water body throughout the Holocene. The lake was often exposed to increased water mixing, especially after $4000 \mathrm{yr}$ cal BP, and this was reflected by the deposition of varved and non-varved sediments and by the production of extreme morphs by the cladoceran species of the family Bosminidae. The com- 
parison with other studies on subfossil Cladocera in long sediment cores suggests that the production of morphologically variable forms was the mechanism that enabled the zooplanktonic organisms to adapt to changing biotic (pressure of predators) and abiotic conditions (temperature, turbid water). The best lacustrine conditions for the development of fauna occurred during the sedimentation of well varved sediments, which is reflected by the increase of abundance of all species, which are indicators of higher nutrient availability. Increases in the zooplankton frequency and, at the same time, in the lake trophic status coincided with the periods of climate warming in the early and middle Holocene and with the impact of human colonisation during successive phases from the late Neolithic to present day.

The comparison of subfossil Cladocera evolution during the entire Holocene in two lakes with laminated sediments, i.e. Lake Tiefer See (Germany) and Lake Gościąż (Poland), outlined significant differences which were responsible for the different Cladocera-inferred reconstruction of the long term trophic evolution of the two lakes. This is noteworthy when considering that the two lakes are located in a similar geographical zone, that both are influenced by oceanic climate regime, and that they are scarcely affected by direct human impact. The meromixis was likely a key factor for the evolution of Lake Gościąż, whereas the frequent water mixing stages were determinant for Lake Tiefer See.

The results provided by the investigation of annually laminated sediments excellent reference material for reconstructing of the past cladoceran dynamics and lacustrine environments, as well as for predicting future ecological trends especially in connection of human impact.

\section{ACKNOWLEDGMENTS}

This study is a contribution to the Virtual Institute of Integrated Climate and Landscape Evolution Analysis (ICLEA) of the Helmholtz Association (grant number VH-VI-415) and used infrastructure of the Terrestrial Environmental Observatory (TERENO). Furthermore, this research was possible with a support of the Institute of Geological Sciences, Polish Academy of Sciences. I wish to thank Achim Brauer and Nadine Dräger (GFZ German Research Centre for Geosciences, Potsdam, Germany) for providing sediment samples and additional data for this review. I am also thankful to all technicians, who helped in the laboratory and subfossil Cladocera analysis, to Edyta Zawisza and Nadine Dräger for valuable comments on the original manuscript, and to two anonymous reviewers and the editors for very constructive remarks to improve this manuscript.

\section{REFERENCES}

Alhonen P, 1970. On the significance of the planktonic/littoral ratio in the cladoceran stratigraphy of lake sediments. Comm. Biol. 35:1-9.

Bennion H, Battarbee RW, Sayer CD, Simpson GL, Davidson TA, 2011. Defining reference conditions and restoration targets for lake ecosystems using palaeolimnology: a synthesis. J. Paleolimnol. 45:533-544.

Błędzki LA, Rybak JI, 2016. Freshwater crustacean zooplankton of Europe. Springer, Switzerland: 918 pp.

Błędzki LA, Szeroczyńska K, Puusepp E, 2013. The late Holocene appearance of European Bosmina (Eubosmina) thersites (Crustacea, Cladocera) in lakes surrounding the Baltic Sea. Hydrobiologia 715:77-86.

Błędzki LA, Szeroczyńska K, 2015. Palaeolimnological evidence of Bosmina morphotypes appearance in the late Holocene. Holocene 25:557-561.

Boucherle MM, Züllig H, 1983. Cladoceran remains as evidence of change in trophic state in three Swiss lakes. Hydrobiologia 103:141-146.

Brauer A, 2004. Annually laminated lake sediments and their palaeoclimatic relevance, p. 109-127. In: H. Fischer, T. Kumke and G. Lohmann G (eds.), The climate in historical times. Springer, Berlin.

Brauer A, Enders C, Negendank JFW, 1999. Lateglacial calendar year chronology based on annually laminated sediments from Lake Meerfelder Maar, Germany. Quat. Int. 61:17-25.

Brauer A, Casanova J, 2001. Chronology and depositional processes of the laminated record from Lac d'Annecy, French Alps. J. Paleolimnol. 25:163-177.

Brooks JL, Dodson SI, 1965. Predation, body size, and composition of plankton. Science 150:28-35.

Chen G, Dalton C, Taylor D, 2010. Cladocera as indicators of trophic state in Irish lakes. J. Paleolimnol. 44:465-481.

Cottenie K, De Meester L, 2003. Connectivity and cladoceran species richness in a metacommunity of shallow lakes. Freshwater Biol. 48:823-832.

De Sellas AM, Paterson AM, Sweetman JN, Smol JP, 2008. Cladocera assemblages from the surface sediments of southcentral Ontario (Canada) lakes and their relationships to measured environmental variables. Hydrobiologia 600:105-119.

Dräger N, Theuerkauf M, Szeroczyńska K, Wulf S, Tjallingii R, Plessen B, Kienel U, Brauer A, 2016. Varve microfacies and varve preservation record of climate change and human impact for the last 6000 years at Lake Tiefer See (NE Germany). Holocene doi: 101177/0959683616660173.

Faustova M, Sacherova V, Svensson JE, Taylor DJ, 2011. Radiation of European Eubosmina (Cladocera) from Bosmina (E.) longispina - concordance of multipopulation molecular data with paleolimnology. Limnol. Oceanogr. 56:440-450.

Flössner D, 2000. [Die Haplopoda und Cladocera Mitteleuropas].[Book in German]. Backhuys Publishers, Leiden: $440 \mathrm{pp}$.

Frey DG, 1986. Cladocera analysis, p. 667-692. In: B.E. Berglund (ed.), Handbook of Holocene palaeoecology and palaeohydrology. J. Wiley \& Sons, Chichester.

Gąsiorowski M, Szeroczyńska K, 2004. Abrupt changes in Bosmina (Cladocera, Crustacea) assemblages during the history of the Ostrowite Lake (northern Poland). Hydrobiologia 
526:137-144.

Gliwicz ZM, 1990. Food thresholds and body size in cladocerans. Nature 343:638-640.

Gliwicz ZM, Pijanowska J, 1989. The role of predation in zooplankton succession, p. 253-296. In: U. Sommer (ed.), Plankton ecology: succession in plankton communities. Springer, Heidelberg.

Gliwicz ZM, Rutkowska AE, Wojciechowska J, 2000. Daphnia populations in three interconnected lakes with roach as the principal planktivore. J. Plankton Res. 22:1539-1557.

Günther J, Lieder U, 1993. Postglacial succession in the subgenus Eubosmina (Crustacea: Cladocera) in the region of the Unterhavel River (near Berlin, Germany) - Type changes or species immigration? Int. Rev. ges. Hydrobiol. 78:1-19.

Hall RI, Smol JP, 1996. Paleolimnological assessment of longterm water quality changes in south-central Ontario lakes affected by cottage development and acidification. Can. J. Fish. Aquat. Sci. 53:1-17.

Hann BJ, Leavitt PR, Chang PSS, 1994. Cladocera community response to experimental eutrophication in Lake 227 as recorded in laminated sediments. Can. J. Fish. Aquat. Sci. 51:2312-2321.

Hellsten AE, Stenson JAE, 1995. Cyclomorphosis in a population of Bosmina coregoni. Hydrobiologia 312:1-9.

Hofmann W, 1984. Postglacial morphological variation in Bosmina longispina Leydig (Crustacea, Cladocera) from Grosser Plöner See (north Germany) and its taxonomic implications. Z. zool. Syst. Evol. -forsch. 22:294-301.

Hofmann W, 1993a. Late-glacial / Holocene changes of the climatic and trophic conditions in three Eifel maar lakes, as indicated by faunal remains. I. Cladocera. Lect. Notes in Earth Sci. 49:393-420.

Hofmann W, 1993b. Morphological variation in the planktonic cladoceran Bosmina (Eubosmina) in the Selenter See. Faunist.-Ökol. Mitt. 6:479-485.

Hofmann W, 1996. Empirical relationships between cladoceran fauna and trophic state in thirteen northern German lakes: analysis of surficial sediments. Hydrobiologia 318:195-201.

Hofmann W, 1999. Holocene succession and morphological variation of the Bosmina (Eubosmina) taxa of the Plußsee (northern Germany). Arch. Hydrobiol. Spec. Issues Advanc. Limnol. 54:359-372.

Hofmann W, 2001. Late-Glacial/Holocene succession of the chironomid and cladoceran fauna of the Soppensee (Central Switzerland). J. Paleolimnol. 25:411-420.

Jeppesen E, Jensen JP, Sǿndergaard M, Lauridsen T, Landkildehus F, 2000. Trophic structure, species richness and biodiversity in Danish lakes; changes along phosphorus gradient. Freshwater Biol. 45:201-218.

Juggins S, 2007. C2 ver. 1.5 user guide. Software for Ecological and Palaeoecological Data Analysis and Visualisation. Newcastle University, Newcastle Upon Tyne, UK 73.

Kamenik C, Szeroczyńska K, Schmidt R, 2007. Relationships among recent Alpine Cladocera remains and their enviroment: implications for climate-change studies. Hydrobiologia 595:33-46.

Kemp AES, 2016. Laminated sediments as paleo-indicators. In: A.E.S. Kemp (ed.), Palaeoclimatology and palaeoceanography from laminated sediments. Geological Society Special Publication No. 116:70-120.
Kerfoot WC, 1981. Long-term replacement cycles in cladoceran communities: a history of predation. Ecology 62:216-233.

Kerfoot WC, 2006. Baltic Eubosmina morphological radiation: sensitivity to invertebrate predators (induction) and observations on genetic differences. Arch. Hydrobiol. 167:147-168.

Kienel U, Dulski P, Ott F, Lorenz S, Brauer A, 2013. Recently induced anoxia leading to the preservation of seasonal laminae in two NE-German lakes. J. Paleolimnol. 50:535-544.

Kinder M, Tylman W, Enters D, Piotrowska N, Poręba G, Zolitschka B, 2013. Construction and validation of calendaryear time scale for annually laminated sediments - an example from Lake Szurpity (NE Poland). GFF 135:248-257.

Korhola A, Rautio M, 2001. Cladocera and other brachiopod crustaceans, p. 5-41. In: J.P. Smol, H.J.B. Birks and W.M. Last (eds.), Tracking environmental change using lake sediments. 4. Zoological indicators. Kluwer, Dordrecht.

Korosi JB, Paterson AM, DeSellas AM, Smol JP, 2008. Linking mean body size of pelagic Cladocera to environmental variables in Precambrian Shield lakes: a paleolimnological approach. J. Limnol. 67:22-34.

Korosi JB, Paterson AM, DeSellas AM, Smol JP, 2010. A comparison of pre-industrial and present-day changes in Bosmina and Daphnia size structure from soft-water Ontario lakes. Can. J. Fish. Aquat. Sci. 67:754-762.

Korosi JB, Smol JP, 2012. Contrasts between dystrophic and clearwater lakes in the long-term effects of acidification on cladoceran assemblages. Freshwater Biol. 57:2449-2464.

Korosi JB, Kurek J, Smol JP, 2013. A review on utilizing Bosmina size structure archived in Lake sediments to Inter hidtoric Shift in predation Reims. J. Plankton Res. 35:444-460.

Kulesza P, Suchora M, Pidek IA, Alexandrowicz WP, 2011. Chronology and directions of Late Glacial paleoenvironmental changes: a multi-proxy study on sediments of Lake Slone (SE Poland). Quater. Int. 238:89-106.

Last WM, Smol JP, 2001. Tracking environmental change using lake sediments. 2. Physical and geochemical methods. Kluwer, Dordrecht: 504 pp.

Lord H, Lagergren R, Svensson JE, Lundqvist N, 2006. Sexual dimorphism in Bosmina: The role of morphology, drag, and swimming. Ecology 87:788-795.

Manca M, Comoli P, 1996. Reconstructing population size structure in Cladocera by measuring their body remains. Mem. Ist. Ital. Idrobiol. 54:61-67.

Manca M, Torretta B, Comoli P, Amsinck SL, Jeppesen E, 2007. Major changes in trophic dynamics in large, deep, sub-alpine Lake Maggiore from 1940s to 2002: a high resolution comparative palaeo-neolimnological study. Freshwater Biol. 52:2256-2269.

Milan M, 2016. Long-term development of subalpine lakes: effects of nutrients, climate and hydrological variability as assessed by biological and geochemical sediment proxies. Ph.D. Thesis, Umeå University, Sweden.

Milecka K, Szeroczyńska K, 2005. Changes in macrophytic flora and planctonic organisms in Lake Ostrowite, Poland, as a response to climatic and trophic fluctuactions. Holocene 15:74-84.

Mingram J, Negedank JFW, Brauer A, Berger D, Hendrich A, Köhler M, Unsinger H, 2007. Long cores from small lakes - recovering up to $100 \mathrm{~m}$-long lake sediment sequences with a high-precision rod-operated piston corer (Unsiger-corer). 
J. Paleolimnol. 37:517-528.

Mirosław-Grabowska J, Zawisza E, 2014. Late Glacial-early Holocene environmental changes in Charzykowskie Lake (northern Poland) based on oxygen and carbon isotopes and Cladocera data. Quarter. Int. 328/329:156-166.

Moore M, Folt C, 1993. Zooplankton body size and community structure: effects of thermal and toxicant stress. Trends Ecol. Evol. 8:178-183.

Nevalainen L, Luoto TP, 2016. Relationship between cladoceran (Crustacea) functional diversity and lake trophic gradients. Funct. Ecol. doi:10.1111/1365-2435.12737.

Niska M, Mirosław-Grabowska J, 2015. Eemian environmental changes recorded in lake deposits from Rzecino (NW Poland): Cladocera, isotopic and selected geochemical data. J. Paleolimnol. 53:89-105.

Nykänen M, Malinen K, Liukkonen M, Kairesalo T, 2010. Cladoceran community responses to biomanipulation and re-oligotrophication in Lake Vesijärvi, Finland, as inferred from remains in annually laminated sediment. Freshwater Biol. 55:1164-1181.

Ralska-Jasiewiczowa M, Goslar T, Madeyska T, Starkel L (eds.), 1998. Lake Gościąż, Central Poland - A Monographic Study, Part I W. Szafer Institute of Botany, Krakow: 340 pp.

Sakamoto M, Kwang-Hyeon C, Hanazato T, 2007. Plastic phenotypes of antennule shape in Bosmina longirostris controlled by physical stimuli from predators. Limnol. Oceanogr. 52: 2072-2078.

Sakamoto M, Hanazato T, 2008. Antennule shape and body size of Bosmina: key factors determining its vulnerability to predacious Copepoda. J. Limnol. 9:27-34.

Sarmaja-Korjonen K, 2001. Correlation of fluctuations in cladoceran planktonic: littoral ratio between three cores from a small lake in southern Finland: Holocene water-level changes. Holocene 11:53-63.

Schmidt R, Muller J, Drescher-Schneider R, Szeroczyńska K, Barri A, Krisai R, 2001. Changes in Holocene lake level and production in a large northern Adriatic karstic lake (Lake Vrana, Cres, Croatia). Terra Nostra 1:53-56.

Sienkiewicz E, Gąsiorowski M, 2016. The effect of fish stocking on mountain lake plankton communities identified using palaeobiological analyses of bottom sediment cores, J. Paleolimnol. 55:129-150.

Sweetman JN, Finney BP, 2003. Differential responses of zooplankton populations (Bosmina longirostris) to fish predation and nutrient loading in an introduced and natural sockeye salmon nursery lake on Kodiak Island, Alaska, USA. J. Paleolimnol. 30:183-193.

Szeroczyńska K, 1998a. The Holocene cladoceran succession in the laminated sediments of Lake Gościąż, p. 219-225. In: M. Ralska-Jasiewiczowa, T. Goslar, T. Madeyska and L. Starkel (eds), Lake Gościąż, Central Poland - A monographic study, Part I. W. Szafer Institute of Botany, Krakow.

Szeroczyńska K, 1998b. Anthropogenic transformation of nine lakes in Central Poland from Mesolithic to modern times in the light of Cladocera analysis. Stud. Geol. Pol. 112:123-165.

Szeroczyńska K, 2006. The significance of subfossil Cladocera in stratigraphy of Late Glacial and Holocene. Stud. Quarter. 23:37-45

Szeroczyńska K, Sarmaja-Korjonen K, 2007. Atlas of Subfossil Cladocera from Central and Northern Europe. Friends of the Lower Vistula Society, Świecie: 84 pp.

Sturm M, 1979. Origin and composition of plastic varves, $p$. 281-285. In: C. Schlüchter (ed.), Moraines and Varves. A.A. Balkema, Rotterdam.

Sturm M, Lotter AF, 1995. Lake sediments as environmental archives. EWAG News 38:6-9.

Tylman W, Szpakowska K, Ohlendorf C, Woszczyk M, Zolitschka B, 2012. Conditions for deposition of annually laminated sediments in small meromictic lakes: a case study of Lake Suminko (northern Poland). J. Paleolimnol. 47:55-70.

Tylman W, Zolitschka B, Enters D, Olehndorf C, 2013. Laminated lake sediments in northeast Poland: distribution, preconditions for formation and potential for paleoenvironmental investigation. J. Paleolimnol. 50:487-503.

Van Damme K, Kotov AA, 2016. The fossil record of the Cladocera (Crustacea: Branchiopoda): Evidence and hypotheses. Earth Sc. Rev. 163:162-189.

Wulf S, Dräger N, Ott F, Serb J, Appelt O, Guðmundsdóttir E, van den Bogaard C, Słowiński M, Błaszkiewicz M, Brauer A, 2016. Holocene tephrostratigraphy of varved sediment records from Lakes Tiefer See (NE Germany) and Czechowskie (N Poland). Quater. Sc. Rev. 132:1-14.

Zawiska I, Słowiński M, Correa-Metrio A, Obremska M, Luoto T, Nevalainen L, Woszczyk M, Milecka K, 2015. The response of a shallow lake and its catchment to Late Glacial climate changes - A case study from eastern Poland. Catena 126:1-10.

Zawisza E, Szeroczyńska K, 2007. The development history of Wigry Lake as shown by subfossil cladocera. Geochronometria 27:67-74.

Zolitschka B, 2007. Varved lake sediments, p. 3105-3114. In: S.A. Elias (ed.), Encyclopedia of quaternary sciences. Elsevier.

Zolitschka B, Francus P. Ojala AEK, Schimmelmann A, 2015. Varves in lake sediments - a review. Quaternary Sci. Rev. 117:1-41. 